KS. ZBIGNIEW JANCZEWSKI

Wydział Prawa Kanonicznego

Uniwersytetu Kardynała Stefana Wyszyńskiego w Warszawie

\title{
KONIECZNOŚĆ ODŁOŻENIA CHRZTU DZIECKA WYZWANIEM DLA EWANGELIZACJI JEGO RODZICÓW
}

Treść: Wstęp. - 1. Wiara rodziców a prawo do chrztu niemowląt - rys historyczny. -2 . Wymogi prawne stawiane rodzicom dla udzielenia chrztu ich dziecku. - 3. Kwalifikacje chrzestnych. - 4. Odłożenie chrztu i ewangelizacja rodziców. - Zakończenie.

\section{Wstęp}

Chrzest stanowi fundament całego życia chrześcijańskiego, otwierający człowiekowi dostęp do pozostałych sakramentów. Dzieci przychodzą na świat $z$ naturą upadłą i skażoną grzechem. Potrzebują więc nowego narodzenia w chrzcie, aby zostały wyzwolone $\mathrm{z}$ mocy grzechu i przeniesione do Królestwa wolności dzieci Bożych, do którego są powołani wszyscy ludzie. Gdyby Kościół i rodzice nie dopuszczali dziecka do chrztu już w okresie niemowlęctwa, pozbawialiby je łaski osiągnięcia dziecięctwa Bożego. Aby łaska ta mogła się jednak później rozwijać, potrzebna jest pomoc, przede wszystkich samych rodziców, a także chrzestnych. Stąd, powinni oni posiadać głęboką wiarę, uzdalniającą służyć pomocą nowo ochrzczonemu ${ }^{1}$.

Niestety coraz częściej obserwuje się rodziców, proszących o chrzest swojego potomstwa, których wiara jest słaba, albo wręcz „szczątkowa”. Przed Kościołem pojawia się zatem zadanie pogłębienia

\footnotetext{
${ }^{1}$ Katechizm Kościoła Katolickiego, Poznań 1994, n. 1250; 1255.
} 
jej, zanim jeszcze ich dziecku zostanie udzielony sakrament, ponieważ do własnych, poważnych obowiązków duszpasterzy należy troska o katechizację powierzonych im wiernych, ażeby ich wiara, przez przyjmowanie nauki i doświadczenia chrześcijańskiego, stawała się żywa, wyraźna i czynna². Powyższa publikacja zajmuje się kwestią wykorzystania prawnej możliwości odłożenia chrztu dziecka, aby przeznaczyć wygospodarowany w ten sposób czas na ewangelizację jego rodziców, w celu wzbudzenia lub pogłębienia ich wiary, koniecznej w przyszłości do religijnego wychowania ochrzczonego potomstwa.

\section{Wiara rodziców a prawo do chrztu niemowląt - rys historyczny}

Dla Kościoła pierwszych wieków, podstawę praktyki chrztu małych dzieci stanowiły wypowiedzi Jezusa, w których zachęcał rodziców, aby nie utrudniali swojemu potomstwu zbliżania się do Niego, ponieważ to właśnie do nich należy Królestwo Boże ${ }^{3}$. Dzieci więc mają prawo wstępu do tegoż Królestwa, co stanowi wystarczającą rację za dopuszczaniem niemowląt do sakramentu chrztu ${ }^{4}$. Taka praktyka, jak się wydaje, istniała już w czasach apostolskich. Dzieje Apostolskie wspominają chrzest niejakiego Korneliusza, który przyjął go wraz z całym swoim domem ${ }^{5}$. Podobna sytuacja miała miejsce w przypadku przyjęcia pierwszego z sakramentów przez pobożną kobietę - Lidię ${ }^{6}$, strażnika więzienia ${ }^{7}$, czy przełożonego synagogi Kryspusa $^{8}$. Kiedy chrzczono „cały dom”, czyniono to w odniesieniu

\footnotetext{
${ }^{2}$ Kan. 773.

${ }^{3} \mathrm{Mk} 10,14$.

${ }^{4}$ L. Balter, Teologiczne problemy chrztu dzieci, Studia Theologica Varsaviensia 13(1975) nr 1, s. 14.

${ }^{5} \mathrm{Dz} 11,14$.

${ }^{6} \mathrm{Dz} 16,15$.

${ }^{7} \mathrm{Dz} 16,33$.

${ }^{8} \mathrm{Dz} 18,8$.
} 
do ojca rodziny (pater familias), współmałżonki, służby i domowników, do których należało potomstwo gospodarza, lub gospodyni tego domu?

Podobna praktyka istniała w II wieku, o czym zaświadcza św. Polikarp (+ 156), który osobiście przyjął chrzest jako małe dziecko ${ }^{10}$. Orygenes (ok. 185-254) wprost twierdzi, że Kościół pierwotny odziedziczył ją od Apostołów ${ }^{11}$. Inny wczesnochrześcijański pisarz, Hipolit Rzymski (+ ok. 235) podaje, ze małym dzieciom udzielano chrztu podczas tego samego obrzędu co osobom dorosłym, jednakże na pytania o wiarę stawiane przez celebransa katechumenowi, w przypadku dzieci odpowiadali jego rodzice ${ }^{12}$.

Istniały też rejony, w których aż do $V$ wieku sprzeciwiano się takowej praktyce. Należała do nich Afryka północna, do czego przyczyniła się herezja pelagianizmu ${ }^{13}$. Dopiero w roku 418 Synod Kartagiński zagroził karami kościelnymi osobom podważającym możliwość i potrzebę udzielania chrztu niemowlętom ${ }^{14}$.

Udzielanie chrztu dzieciom uzasadnia św. Augustyn (353-430). Niemowlęta przynosi się do świątyni, użyczając niejako własnych nóg, których one nie potrafią jeszcze używać. Kościół użycza się im również serca, aby same mogły wierzyć $i$ języka do wyznania tej wiary. Kościół więc okazuje się matką przynoszonych do sakramenmtu, ponieważ zawsze wypowiadał się za możliwością chrztu niemowląt, przejął ją od wcześniejszych pokoleń chrześcijan i będzie jej strzegł do końca swojej egzystencji na ziemi ${ }^{15}$. Według Pastuszki w czasach

\footnotetext{
${ }^{9}$ J. Kudasiewicz, Praktyka i teologia chrztu w Kościele pierwotnym, Kielecki Przegląd Diecezjalny 42(1976) s. 30.

${ }^{10}$ J.M. Szymusiak, M. StarowiejSki, Słownik wczesnochrześcijańskiego piśmiennictwa, Poznań 1971, s. 329.

${ }^{11}$ In Romanos commentarii, 5, 9, w: PG 14, 1047.

${ }^{12}$ B. Bote, La Tradition apostolique de Saint Hippolyte, essai de reconstitution, n. 21, Munster Westfallen 1963, s. 45.

${ }^{13}$ M. Pastuszko, Prawo o sakramentach św. Normy ogólne i sakrament chrztu, Warszawa 1983, s. 136.

${ }^{14}$ Can. 2, w: Mansi 4, 327.

${ }^{15}$ Sermo CLXXVI, 2, w: PL 38, 950.
} 
papieża Celestyna I (422-432) praktyka udzielania chrztu noworodkom była już powszechna w całym Kościele ${ }^{16}$.

Pod koniec $\mathrm{V}$ wieku diakon Jan przyznaje, że podczas chrztu dzieci nie używających jeszcze rozumu, wiarę w ich zastępstwie wyznają rodzice, lub inne osoby przynoszące je do sakramentu. Wiara innych osób pomaga im bowiem do zbawienia, podobnie jak wcześniej zaszkodził im grzech innych ${ }^{17}$. Podobnie argumentuje Izydor z Sewilli (+636), twierdząc, że tak jak za głuchych lub niemych ktoś za nich mówi podczas chrztu, tak też za niemowlęta ktoś inny wyraża wiarę przy udzielaniu sakramentu ${ }^{18}$. Wiara dzieci jest wspomagana przez wiarę rodziców, dodaje Beda Venerabilis $(+735)^{19}$.

Sobór Trydencki w latach 1545-1547 odrzucił opinię, według której niemożliwy jest chrzest niemowląt, ponieważ nie są one w stanie wyznać osobiście wiary podczas obrzędu, a gdyby zostały ochrzczone, akt taki byłby nieważnym oraz że lepiej jest zaniechać sakramentu, niż chrzcić je tylko w wierze Kościoła ${ }^{20}$.

Podsumowując powyższe rozważania, należy stwierdzić fakt, że od początku chrześcijaństwa istniała praktyka udzielania chrztu niemowlętom. Opierała się ona na głębokim przekonaniu, iż wiara, której nie mają jeszcze takie dzieci, jest niejako uzupełniana przez wiarę całego Kościoła, a szczególnie osób, które będą w niej wychowywać swoje potomstwo, czyli rodziców. Wiara stanowi więc konieczny, nieodzowny element decydujący o udzieleniu człowiekowi pierwszego sakramentu wtajemniczenia chrześcijańskiego, jednak w przypadku małego dziecka, wspomnianą wiarę wyznają w jego imieniu osoby przynoszące je do świątyni.

Jak pisze Skowronek, osobowość dziecka budzi się nie na skutek kontaktu ze światem rzeczy, ale przez proces obcowania z drugą osobą, matką pełną miłości i oddania. To właśnie stanowi antropologiczną

\footnotetext{
${ }^{16}$ M. Pastuszko, dz. cyt., s. 138.

${ }^{17}$ Epistola ad Senarium virum illustrum, III, w: PL 49, 403.

${ }^{18}$ De ecclesiasticis officis, II, 25,7, w: PL 83, 822.

${ }^{19}$ In Marcum, 7, w: PL 92, 203.

${ }^{20}$ Sess. VII, can. 13, w: DSP, t. 4, s. 362-363.
} 
podstawę, którą uwzględnia Kościół udzielając chrztu niemowlętom niezdolnym do aktu wiary, nadziei i miłości oraz żalu za grzechy. Nie tyle wierzący rodzice mają prawo prosić o chrzest dla swojego potomka, ile w pierwszym rzędzie prawo do chrztu przysługuje dziecku, prawo do integrowania $\mathrm{z}$ całą rodziną Bożą, uczestnictwa w tej samej wierze, jaką wyznają ci, którzy są naturalnymi współtwórcami jego $\dot{z} y c i a^{21}$. Wiara ta jednak musi istnieć przynajmniej w minimalnym stopniu i wyrażać się na zewnątrz w życiu codziennym rodziców. Jeśli jej brakuje, pojawia się postulat jakiegoś oddziaływania pastoralnego na rodziców, w celu wzbudzenia tego nieodzownego elementu, pozwalającego na religijne wychowanie potomstwa.

\section{Wymogi prawne stawiane rodzicom dla udzielenia chrztu ich dziecku}

Na temat wolności chrztu dzieci, wiary całej wspólnoty kościelnej oraz ich rodziców, jak też odniesienia tejże wiary do chrztu niemowląt, a także odpowiedniości chrztu dzieci, prowadzi się obecnie żywe dyskusje. Jak się wydaje, wiele z tych kwestii wymaga rozwiązania, a niektóre z nich, jak zauważa Testa, pozostaną być może wciąż dyskusyjne i będą rozstrzygane na różne sposoby, ponieważ przeplatają się w nich kwestie zarówno doktrynalne, jak i duszpasterskie ${ }^{22}$. Chrzest małego dziecka może mieć miejsce, o ile jego rodzice, albo prawni opiekunowie, spełnią kryteria, stawiane przed nimi przez normy Kodeksu prawa kanonicznego ${ }^{23}$.

Dla godziwego udzielenia interesującego nas sakramentu, potrzebna jest najpierw zgoda obojga rodziców, a przynajmniej jednego z nich lub osób prawnie ich zastępujących ${ }^{24}$. Wymóg ten, zwłaszcza jeśli chodzi o dobro duchowe dziecka, należy interpretować w szerszym

\footnotetext{
${ }^{21}$ A Skowronek, Z teologii chrztu, w: Sakrament chrztu, Katowice 1973, s. 20-21.

${ }^{22}$ B. Testa, Sakramenty Kościoła, tłum. L. Balter, Poznań 1998, s. 148.

${ }^{23}$ Kan. 868 par. 1.

24 Tamże, pkt 1.
} 
znaczeniu ${ }^{25}$. Zgoda może być wyrażona w jakikolwiek sposób, zarówno ustnie, jak i na piśmie, byleby była rzeczywista. Niekonieczne jest wyrażenie jej jasne i wyraźne, wystarcza ujawnienie aktu swojej woli implicite ${ }^{26}$.

Bardziej interesującym nas w kontekście rozpatrywanego w tej publikacji problemu jest konieczność zaistnienia uzasadnionej nadziei, że dziecko w przyszłości otrzyma katolickie wychowanie. Norma ponadto postanawia, iż w przypadku zupełnego braku takowej, chrzest należy odłożyć zgodnie z przepisami prawa partykularnego, wskazując rodzicom na rację takiej decyzji ${ }^{27}$. W tym kontekście należy jeszcze raz przypomnieć, że chrzest jest konieczny do zbawienia, będąc znakiem i narzędziem miłości Bożej, uwalniającym od grzechów i wprowadzającym do wspólnoty życia z Bogiem. Z drugiej strony wymaga się od rodziców proszących o sakrament dla swojego potomstwa pewnych gwarancji, ponieważ, to właśnie oni mogą zapewnić rozwój wiary dziecka, poprzez jego odpowiednie wychowanie. Jeżeli dawane przez nich gwarancje nie są rzeczywiście prawdziwe, sakrament zostanie udzielony wadliwie, nie przynosząc w ostateczności pełnych związanych z nim skutków duchowych. Według Trevisana, jeżeli wymaganej prawnie uzasadnionej nadziei wychowania nie potrafią zagwarantować sami rodzice, $w$ wychowanie religijne mogą niejako wkroczyć inne osoby ze wspólnoty parafialnej - katechiści, chrzestni oraz proboszcz. Cała wspólnota parafialna powinna bowiem głosić ochrzczonemu wiarę i wprowadzać w sakramenty poprzez swoich członków ${ }^{28}$.

Jednak nie można zapominać, że osobami, które zazwyczaj mają największy realny wpływ na wychowanie dzieci, są matka i ojciec. Podstawą takiej sytuacji jest ich naturalne prawo do wychowania

\footnotetext{
${ }^{25}$ J. KRZYwdA, Sakramenty, w: Komentarz do kodeksu prawa kanonicznego, t. 3/2, Poznań 2011, s. 55.

${ }^{26}$ M. PAstuszko, dz. cyt., s. 148.

${ }^{27}$ Kan. 868 par. 1 , pkt 2.

${ }^{28}$ G. Trevisan, La funzione di santificare della Chiesa, w: Codice di diritto canonico commentato, Milano 2009, s. 737.
} 
potomstwa. Osobista wiara dzieci wzrasta bowiem i rozwija się wraz z dojrzewaniem fizycznym i duchowym. Obecność wierzących rodziców podczas takiego procesu, daje nadzieję, że dziecko zostanie wychowane w religii katolickiej. W konkretnej sytuacji życiowej nadzieja taka może się pojawić także ze strony innych członków rodziny, jak dziadkowie lub wujostwo ${ }^{29}$.

Krzywda zauważa, że rozpatrując ten wymóg niejako a contrario, wydaje się rzeczą bezdyskusyjną, iż uzyskanie w tej materii pewności o braku takiej nadziei, w wielu przypadkach nie będzie latwe, lub stanie się niemożliwe. Nie ma więc wątpliwości, że w tak ważnej i delikatnej sprawie, wymagana jest szczególna troska duszpasterzy, przy ocenie wszystkich okoliczności, przed podjęciem właściwej decyzji. Jeśli jednak ostatecznie zachodzi konieczność podjęcia tymczasowo decyzji na „niekorzyść” dziecka, należy rodzicom jasno i taktownie przedstawić powody, jakie wpłynęły na odłożenie chrztu. Przy uwzględnianiu konieczności zapewnienia katolickiego wychowania dziecka, oprócz rodziców, należy również mieć na uwadze postawę religijną jego chrzestnych oraz bliskich krewnych ${ }^{30}$.

Duszpasterz decydujący o udzieleniu chrztu niemowlęciu, podczas rozmowy z jego rodzicami w kancelarii, powinien zwrócić szczególną uwagę na omówiony powyżej wymóg prawny. Trzeba też realistycznie zastanowić się z tymi osobami, czy ich postawa religijna daje rzeczywistą nadzieję na religijne wychowanie, a w przypadku braku takowej zaproponować inne rozwiązanie, którego konsekwencją może się stać zmiana sposobu życia przynajmniej jednego z rodziców.

Wyjaśniając tą kwestię należałoby zwrócić między innymi uwagę na słowa, które wypowiadają rodzice i chrzestni podczas liturgicznych ceremonii chrztu, kiedy to powinni nie tylko publicznie wyznać swoją wiarę, ale również wyrzec się grzechu i wszystkiego, co prowadzi do zła i szatana. Jeżeli deklaracje te są w rzeczywistości bez pokrycia w ich życiu, stanowią formę oszustwa zarówno w odniesieniu do

\footnotetext{
${ }^{29}$ B. F. Pighin, Diritto sacramentale, Venezia 2006, s. 115.

${ }^{30}$ J. KRZYWDA, dz. cyt., s. 55.
} 
przyjmującego sakrament niemowlęcia, jak i całej wspólnoty Kościoła, dopuszczającej do takiej ceremonii.

Jeśli rodzice mimo to nie odstępują od prośby o chrzest, należałoby jak się wydaje, zaproponować im poddanie się wcześniej jakiejś formie katechizacji.

\section{Kwalifikacje chrzestnych}

Instytucja rodziców chrzestnych nie jest konsekwencją ludowego zwyczaju. Swoimi korzeniami, jak pisze Skowronek, sięga najgłębszych pokładów ludzkiej egzystencji. Każdy człowiek potrzebuje do życia czyjejś pomocy. W sytuacji, kiedy rodzicom zależy na szczęściu swojego potomstwa, tym bardziej zarówno pod kołyską, jak i przy chrzcielnicy stawiają odpowiedzialne osoby. Ponadto chrzestni są oficjalnymi przedstawicielami Kościoła, w którego życie dziecko zostaje włączone przez sakrament. Stąd powinny być nimi osoby świadome przynależności do Kościoła ${ }^{31}$.

Jak to już zostało powiedziane, również chrzestni powinni w pewnym stopniu stać się gwarantami religijnego wychowania dziecka po chrzcie. Norma kodeksowa zobowiązuje ich do przedstawienia razem $z$ rodzicami dziecka do chrztu oraz do pomocy, aby prowadziło życie zgodnie z wymogami przyjętego sakramentu, wypełniając wiernie złączone z nim obowiązki ${ }^{32}$. Zobowiązanie to, jak twierdzi Sopoćko, wynika niejako z kontraktu, jakie chrzestni zawierają z chrześniakiem w formie przyrzeczenia i które rozciąga się na całe jego życie. Ranga tej odpowiedzialności wynika z samej natury rzeczy, ponieważ dotyczy szczęścia wiecznego chrześniaka, który powołany przez interesujący nas sakrament na dziedzica Królestwa Bożego, przez ewentualne niedbalstwo chrzestnych, może się narazić na oddalenie się od tegoż Królestwa ${ }^{33}$.

\footnotetext{
${ }^{31}$ A. Skowronek, dz. cyt., s. 67.

${ }^{32}$ Kan. 872.

${ }^{33}$ M. Sopoćko, Obowiązki rodziców chrzestnych, Ateneum Kapłańskie 38(1936) s. 185.
} 
Warto zauważyć, iż normy kodeksowe stawiają przed takimi osobami o wiele większe wymagania, niż przed naturalnymi rodzicami małego katechumena. Należą do nich:

a) ukończenie szesnastego roku życia, chyba że biskup diecezjalny określił inny wiek, albo proboszcz lub szafarz, kierując się słuszną racją, w drodze wyjątku dopuszcza chrzestnego,

b) przynależność do Kościoła katolickiego, przyjęcie wszystkich sakramentów wtajemniczenia chrześcijańskiego oraz prowadzenie życia zgodnego $\mathrm{z}$ wiarą, odpowiadające pełnionej funkcji,

c) niepodleganie karze kanonicznej, wymierzonej lub deklarowanej zgodnie z prawem,

d) brak więzów rodzicielskich z przyjmującym sakrament ${ }^{34}$.

Wydaje się, że określenie wymogu wiekowego dla osoby podejmującej się obowiązku chrzestnego wiąże się z pewnym poziomem dojrzałości, z którym można przypuszczać, iż w przypadku niedomagania rodziny naturalnej dziecka pod względem religijnym, chrzestny wzbudza w pewnym stopniu nadzieję, że podejmie się skutecznej pomocy w wychowaniu do chrześcijaństwa swojego chrześniaka. Patrząc z takiej perspektywy, wątpliwości budzi tutaj postanowienie Konferencji Episkopatu Polski, obniżające wymóg wieku do piętnastego roku życia ${ }^{35}$. Czy rodzice dziecka, prowadzący życie nie do końca zgodne z zasadami głoszonymi przez Kościół, będą liczyć się w rzeczywistości z uwagami na temat wychowania ich dziecka ze strony piętnastoletniego chrzestnego? Chyba jednak nie.

Prawnie wymaganej nadziei nie dają również osoby żyjące w ciężkim grzechu, połączonym z zaciągnięciem kar kanonicznych, a ponadto w niesakramentalnym związku małżeńskim ${ }^{36}$ oraz z własnego wyboru nieuczestniczące w katechezie szkolnej. Pighin zauważa

\footnotetext{
${ }^{34}$ Kan. 874 par. 1, p. 2-5.

${ }^{35}$ Instrukcja dla duchowieństwa $w$ związku $z$ wprowadzeniem obrzędów chrześcijańskiego wtajemniczenia dorosłych, n. 5, 9.05.1989, w: Dokumenty duszpastersko-liturgiczne Episkopatu Polski 1966-1993, red. C. Krakowiak, L. Adamowicz, Lublin 1999, s. 23.

${ }^{36}$ G. Trevisan, dz. cyt., s. 741.
} 
natomiast, że do grupy prowadzącej życie niezgodne z wiarą można zaliczyć także nastawionych krytycznie do swojej religii, deklarujących się jako agnostycy oraz pozostających jedynie w związku cywilnym $^{37}$. Wymóg uprzedniego przyjęcia przez chrzestnego wszystkich sakramentów wtajemniczenia chrześcijańskiego ma związek z koniecznością asystowania swojemu chrześniakowi w przygotowaniach do pierwszej Komunii i bierzmowania ${ }^{38}$.

Cytowany już wcześniej kanon postanawia, że na ile jest to możliwe, przyjmujący sakrament powinien mieć przynajmniej jednego chrzestnego $^{39}$. Coraz częściej zdarzają się przypadki, w których rodzice nie są w stanie zaproponować dwóm, a nawet jednej osobie podjęcie się tego obowiązku. Trzeba zauważyć, iż cytowana norma wymaga tylko jednej osoby, nie powinno się zatem powierzać niejako „na siłę” obowiązków przypadkowej, drugiej osobie, jak to się czasami czyni ${ }^{40}$. Taki chrzestny w przyszłości, często nie będzie miał żadnego kontaktu ze swoim chrześniakiem. A co w sytuacji, w której nie można znaleźć nawet jednej osoby spełniające stawiane przez prawo wymagania? Odpowiedź znajdujemy w przytoczonej powyżej normie. Przyjmujący sakrament, o ile jest to możliwe, powinien mieć chrzestnego. Jeżeli więc takiej możliwości nie ma, nie istnieje bezwzględny wymóg jego posiadania. Jednak w takiej sytuacji należy tym bardziej posiąść moralną pewność, że rodzice dziecka są w stanie zapewnić mu religijne wychowanie.

Trzeba jeszcze dodać, że w Kościele katolickim chrzestnym może być wierny należący do niekatolickiego Kościoła wschodniego. Obowiązek czuwania nad wychowaniem chrześcijańskim dziecka, spoczywa jednak wtedy na chrzestnym katolickim ${ }^{41}$. Członkowie innych Kościołów lub wspólnot chrześcijańskich nie mogą pełnić omawianej

\footnotetext{
${ }^{37}$ B. F. Pighin, dz. cyt., s. 125.

${ }^{38}$ Tamże.

${ }^{39}$ Kan. 872.

${ }^{40}$ Proboszczowie nierzadko wyznaczają w takim przypadku na chrzestnego np. miejscowego kościelnego albo organistę.

${ }^{41}$ Directorium Oecumenicum noviter compositum, n. 98 b, 23.03.1993, AAS 85(1993) s. 1098.
} 
funkcji, a jedynie urzędowego świadka chrztu, obok chrzestnego katolickiego ${ }^{42}$.

Chrzestny powinien zatem współdziałać z rodzicami niemowlęcia, które w rzeczywistości swojej egzystencji będzie potrzebowało profesjonalnego przykładu osobistej wiary wspomnianych osób ${ }^{43}$. W sytuacji, kiedy duszpasterz ma do czynienia $\mathrm{z}$ brakiem takiej wiary po stronie zarówno kandydatów na chrzestnych, jak i rodziców dziecka, powinien poważnie rozważyć podjęcie decyzji o odłożeniu chrztu na pewien czas, potrzebny dla nastąpienia istotnych zmian w istniejącej sytuacji.

\section{Odłożenie chrztu i ewangelizacja rodziców}

Możliwość odłożenia chrztu dziecka jest stosunkowo nową normą, wprowadzoną po raz pierwszy po Soborze Watykańskim II, do $O b$ rzędu chrztu dzieci z roku 1969. Znalazła się ona później w Kodeksie prawa kanonicznego papieża Jana Pawła II ${ }^{44}$. Należy zaznaczyć, że ustawodawca nie mówi tutaj o odmowie udzielenia interesującego nas sakramentu, ale o jego odłożeniu. Wiąże się to $\mathrm{z}$ brakiem uzasadnionej nadziei na Katolickie wychowanie dziecka.

Duszpasterz przed wyrażeniem zgody na chrzest dziecka powinien się dowiedzieć, czy jego rodzice żyją jak prawdziwi chrześcijanie, w małżeństwie sakramentalnym, zgodnie z deklarowaną wiarą. Następnie czy wypełniają przynajmniej podstawowe obowiązki religijne, a ich postawa życiowa nie wzbudza zgorszenia po stronie rodziny i środowiska. W przypadku małżeństw niesakramentalnych, zwraca się uwagę na atmosferę religijną w rodzinie ${ }^{45}$.

Według Gerosy, aby odłożenie chrztu było możliwe i prawomocne, należy najpierw:

\footnotetext{
${ }^{42}$ Kan. 874 par. 2.

${ }^{43}$ A. Perlasca, La figura e il ruolo dei padrini nei Sacramento dell'iniziazione cristiana, w: Quando si diventa Cristiani, Milano 2003, s. 321-323.

${ }^{44}$ Kan. 868 par. 1, n. 2.

${ }^{45}$ Z. JANCZEWsKI, Wiara jako zasadniczy warunek przyjęcia chrztu, Prawo Kanoniczne 56(2013) nr 2, s. 54.
} 
a) stwierdzić całkowity brak nadziei na wychowanie dziecka w wierze katolickiej,

b) wziąć pod uwagę normy prawa partykularnego,

c) uprzedzić rodziców o motywach odłożenia.

Pierwszy z warunków uwypukla szczególną naturę podjętego działania, będącego jedynie odłożoną w czasie propozycją przeżywania chrztu, jako sakramentu wiary. Przynagla ona do wzięcia odpowiedzialności w zakresie wychowania, nie tylko przez rodziców, ale przez wszystkie osoby z otoczenia dziecka. Ostatni z wymienionych warunków może być rozumiany jako nieodzowny, w przypadku, kiedy istnieje jakaś uzasadniona wątpliwość, w odniesieniu do katolickiego wychowania $^{46}$.

Warunek gwarancji wychowania, jak zauważa Trevisan, jest niezwykle istotny, ponieważ tylko przy rzeczywistej jego realizacji, podczas prawdziwej edukacji religijnej, w wierze i życiu chrześcijańskim, chrzest pozwoli później dziecku czerpać z pełni łask sakramentalnych. Nie jest tu wymagane, żeby jedynie rodzice przekazywali wychowanie chrześcijańskie, mogą to również czynić chrzestni, katechiści oraz cała parafia. Wspomniany autor, jako warunki do odłożenia chrztu dziecka wymienia następujące:

a) brak pozytywnej woli przekazywania wiary i uczestnictwa w praktykach religijnych dziecka,

b) przedstawienie jako kandydata na chrzestnego osoby, która nie może edukować chrześniaka poprzez nauczanie i przykład uczestnictwa w praktykach religijnych,

c) odrzucenie pomocy ze strony parafii $\mathrm{w}$ formie uczestnictwa w katechezach przedchrzcielnych ${ }^{47}$.

Zobatrzmy teraz, jak omawiany problem reguluje polskie prawo partykularne. Instrukcja duszpasterska o udzielaniu chrztu dzieciom Konferencji Episkopatu Polski z 14-15 grudnia 1977 roku stanowi, że należy dopuszczać do chrztu wszystkie dzieci, zgłoszone przez rodziców lub prawnych opiekunów, jeśli osoby te są wierzące i zobowiązują

\footnotetext{
${ }^{46}$ L. Gerosa, dz. cyt., s. 192-193.

${ }^{47}$ G. Trevisan, dz. cyt., s. 737.
} 
się, do ich wychowania w wierze. W przypadku rodziców żyjących w małżeństwie cywilnym, należy ich doprowadzić do zawarcia ślubu kościelnego, a w razie odmowy, żądać od nich i od chrzestnych złożenia na piśmie oświadczenia, że będą wychowywać potomstwo w wierze katolickiej. Jeżeli jedno z rodziców jest niewierzące, należy udzielić dziecku chrztu. W przypadkach szczególnie trudnych, trzeba się zwrócić do ordynariusza miejsca ${ }^{48}$. Dyspozycje zawarte w tym dokumencie są ogólnikowe i nie pokazują dróg prowadzących do konkretnych rozstrzygnięć. Z jednej strony warunkują możliwość udzielenia chrztu od wiary rodziców, $\mathrm{z}$ drugiej natomiast dopuszczają do niego w przypadku, kiedy postawa życiowa tych osób jest zaprzeczeniem wierze. Dalej zobowiązuje się ich do deklaracji wychowania potomstwa zgodnie z zasadami wiary, przyjmując równocześnie odmowę propozycji zmiany własnego życia i zawarcia sakramentalnego małżeństwa.

Wiadomo, że w Polsce, z różnych przyczyn, zazwyczaj dla podtrzymania tradycji, rodzice nie żyjący po katolicku nierzadko zgłaszają się do duszpasterzy, aby ci ochrzcili ich potomstwo. Jest to znakomita, niepowtarzalna okazja, aby powołując się na normy prawa kanonicznego, skorzystać z możliwości odłożenia chrztu na pewien czas, w którym rodzice poddadzą się niejako reedukacji religijnej. Przepisy prawa zobowiązujące ich do wzięcia udziału w kilku katechezach, powinny się znaleźć $\mathrm{w}$ zbiorze prawa partykularnego, po uchwaleniu przez Konferencję Episkopatu Polski, albo nawet w powszechnym prawie Kościoła.

Pomysłowi można by zarzucić, że nie jest niczym nowym. Rodzice i chrzestni mają bowiem obowiązek wziąć udział w jednej lub kilku tzw. katechezach przedchrzcielnych. Trzeba jednak zauważyć, że takie katechezy kierowane są przede wszystkim do osób żyjących zgodnie z wyznawaną wiarą, którzy stanowią przeważającą większość proszących o chrzest swojego potomstwa. Treść i charakter spotkań z interesującą nas grupą osób powinien być zupełnie inny, niż zwyczajnej katechezy. Należałoby podczas nich przy ogromnym zaangażowaniu

\footnotetext{
${ }^{48}$ Wiadomości Archidiecezji Gnieźnieńskiej 33(1978) nr 5-6, s. 98.
} 
prowadzącego duszpasterza omówić problemy związane z istotą wiary chrześcijańskiej. Kolejnym tematem może się stać problem życiowych konsekwencji przyjęcia wiary przez konkretnego człowieka, roli sakramentów w życiu katolika, z podkreśleniem sakramentu małżeństwa. Dalej, należałoby omówić kwestię zagwarantowania przekazania wiary własnemu dziecku jako konsekwencji oddania go do chrztu, wagi aktu wyrzeczenia się grzechu i szatana, dokonywanego podczas liturgii chrztu w świątyni, a także konsekwencji spływających na dziecko, a wiążących się z decyzją jego rodziców o przyjęciu go do Kościoła.

Omawiane katechezy powinny odbywać się np. co tydzień przez minimum jeden miesiąc. Wzięcie w nich udziału przez rodziców i ewentualnie chrzestnych, stanie się probierzem motywów ich prośby o chrzest. Prawdopodobnie, w przypadku motywacji nie związanej z prawdziwą wiarą, rodzice nie zdecydują się na "stratę czasu” i nie przyjdą na spotkania z duszpasterzem. Trzeba jednak zauważyć, iż taka decyzja będzie równocześnie ich własnym wyborem, świadomą rezygnacją z chrztu, w konsekwencji której, dziecko otrzyma na przyszłość możliwość samodzielnego, dojrzałego włączenia się do Kościoła kiedy dorośnie.

Odłożenie chrztu, na czas katechizacji może zostać uzależnione od wystąpienia równocześnie u obojga rodziców następujących przesłanek:

a) uważają się za osoby niewierzące, albo agnostyków,

b) nie zawarli sakramentalnego małżeństwa mimo braku przeszkód, żyjąc razem w związku cywilnym lub konkubinacie,

c) uważając się za wierzących, odrzucają w nauczaniu Kościoła najważniejsze prawdy wiary i moralności, albo praktykują swoją wiarę sporadycznie (uczestniczą w liturgii niedzielnej tylko kilka razy w roku),

d) będąc formalnie katolikami, należą do sekty satanistycznej, albo stowarzyszenia masońskiego,

e) odrzucają potrzebę wychowania w wierze swojego dziecka przez nauczanie (własne i za pośrednictwem duszpasterstwa) oraz jego uczestnictwo w praktykach religijnych 
f) w przypadku, kiedy postawa obojga rodziców wyczerpuje co najmniej jedną z powyższych przesłanek, inna osoba zgłaszająca ich dziecko do chrztu (np. babcia, opiekun prawny) nie prowadzi życia zgodnego z wyznawaną wiarą, lub nie będzie w stanie realnie wpływać na religijne wychowanie dziecka (odległe zamieszkanie, słaba więź z rodzicami dziecka).

Stawiając przytoczone powyżej wymagania wobec rodziców chcących ochrzcić swoje potomstwo, ${ }^{49}$ Kościół może aktywnie przyczynić się do pogłębienia przez nich wiary, szczególnie w tych czasach, kiedy w krajach tak tradycyjnie katolickich jak Polska, ochrzczone, niejako dla podtrzymania tradycji w wieku niemowlęcym dzieci, wyrastają coraz częściej na osoby obojętne religijnie, a nawet wrogo nastawione do Kościoła katolickiego. Nie mają bowiem wsparcia we własnej, najbliższej rodzinie, zupełnie obojętnej religijnie ${ }^{50}$.

\section{Zakończenie}

Już od początków chrześcijaństwa istniała praktyka udzielania chrztu niemowlętom. Opierała się ona na głębokim przekonaniu, iż wiara, której nie mają jeszcze dzieci, jest uzupełniana przez wiarę całego Kościoła, a szczególnie osób, które będą w niej wychowywać swoje potomstwo, czyli rodziców. Wiara stanowi zatem nieodzowny element, decydujący o udzieleniu człowiekowi pierwszego sakramentu wtajemniczenia chrześcijańskiego, jednak w przypadku małego dziecka, w jego imieniu wyznają ją osoby przynoszące niemowlaka do świątyni.

W związku z tym Najwyższy Prawodawca Kościelny ustanowił niezwykle ważny wymóg, konieczności zaistnienia uzasadnionej nadziei, że dziecko w przyszłości otrzyma katolickie wychowanie. Norma ponadto postanawia, iż w przypadku zupełnego braku takowej, chrzest należy odłożyć zgodnie z przepisami prawa partykularnego, wskazując rodzicom na rację takiego działania.

${ }^{49} \mathrm{Za}$ wyjątkiem punktu f), kiedy to odłożenie chrztu będzie się wiązało z dużo dłuższym czasem, w którym dziecko dorośnie i samo wybierze chrzest.

${ }^{50}$ Z. JANCZEWSKI, dz. cyt., s. 56. 
Duszpasterz decydujący o udzieleniu chrztu niemowlęciu, podczas rozmowy $\mathrm{z}$ jego rodzicami w kancelarii, powinien zatem zwrócić szczególną uwagę na omówiony powyżej wymóg. Trzeba też realistycznie zastanowić się z tymi osobami, czy ich postawa religijna daje rzeczywistą nadzieję na religijne wychowanie, a w przypadku braku takowej zaproponować inne rozwiązanie, którego konsekwencją może się stać zmiana sposobu życia przynajmniej jednego z rodziców.

Wiadomo, że w Polsce, zazwyczaj dla podtrzymania tradycji, rodzice nieżyjący po katolicku zgłaszają się do duszpasterzy, aby ci ochrzcili ich potomstwo. Jest to znakomita, niepowtarzalna okazja, aby powołując się na normy prawa kanonicznego, skorzystać z możliwości odłożenia chrztu na pewien czas, w którym rodzice poddadzą się procesowi ewangelizacji. Przepisy prawa zobowiązujące ich do wzięcia udziału w kilku katechezach, powinny się znaleźć w zbiorze prawa partykularnego, po uchwaleniu przez Konferencję Episkopatu Polski, lub nawet w powszechnym prawie Kościoła.

Treść i charakter spotkań z interesującą nas grupą osób powinien być zupełnie inny, niż zwyczajnej katechezy przedchrzcielnej. Należałoby podczas nich, przy wzmożonym zaangażowaniu prowadzącego duszpasterza, omówić problemy związane z istotą wiary chrześcijańskiej, życiowych konsekwencji przyjęcia wiary przez konkretnego człowieka, roli sakramentów w życiu katolika, z podkreśleniem sakramentu małżeństwa. Ponadto trzeba omówić kwestię zagwarantowania przekazania wiary własnemu dziecku, jako konsekwencji oddania go do chrztu, wagi aktu wyrzeczenia się grzechu i szatana, dokonywanego podczas liturgii sakramentu w świątyni, a także konsekwencji spływających na dziecko, a wiążących się z decyzją jego rodziców o przyjęciu go do Kościoła.

Tego rodzaju katechezy powinny odbywać się co tydzień, przez minimum jeden miesiąc. Wzięcie w nich udziału przez rodziców i ewentualnie chrzestnych, może ujawnić rzeczywiste motywy ich prośby o chrzest. W przypadku motywacji niezwiązanej rzeczywiście wiarą, rodzice prawdopodobnie nie zdecydują się na takie rozwiązanie, nie godząc się na spotkania $z$ duszpasterzem. Trzeba jednak zauważyć, iż ich decyzja będzie równocześnie świadomą rezygnacją 
z chrztu dziecka, w konsekwencji której, otrzyma ono na przyszłość, kiedy dorośnie, możliwość samodzielnego, dojrzałego włączenia się do Kościoła.

\section{Necessity accordance of baptism like a challenge for evangelization of his parents}

Canon 868 paragraph 1 number 2 decides: for an infant to be baptised lawfully it is required: that there be a well-founded hope that the child will be brought up in the catholic religion. If such hope is truly lacking, the baptism is, in accordance with the provisions of particular law. In Poland many Catholics who life is discordant with hope want to baptise his children. This is a special challenge for priests.

They have to chance for reevangelization of such parents. Norms of universal or particular canon low could oblige in this situations to be a party to in extraordinary catechesis. Those catechesis, once a week, minimum by one months, could be take up problems about fundaments of the faith and necessity faith of parents to baptism his children.

SŁOWA KLUCzOWE: chrzest, dziecko, wiara, rodzice, ewangelizacja, otłożenie chrztu

KeY WorDs: baptism, child, faith, parents, evangelization, postponement of baptism

Nota o Autorze:

Ks. PROF. ZW. DR HAB. ZbignieW JANCZeWSKI - pracownik naukowo-dydaktyczny na Wydziale Prawa Kanonicznego Uniwersytetu Kardynała Stefana Wyszyńskiego w Warszawie, kierownik Katedry Prawa o Posłudze Uświęcania. 
